\title{
Material culture of the upper Sepik
}

La culture matérielle du Haut Sepik

\section{Barry Craig}

\section{(2) OpenEdition}

\section{Journals}

\section{Electronic version}

URL: http://journals.openedition.org/jso/8242

DOI: 10.4000/jso.8242

ISSN: $1760-7256$

\section{Publisher}

Société des océanistes

\section{Printed version}

Date of publication: 15 July 2018

Number of pages: 189-201

ISBN: 978-2-85430-135-9

ISSN: 0300-953x

\section{Electronic reference}

Barry Craig, « Material culture of the upper Sepik », Journal de la Société des Océanistes [Online], 146 | 2018, Online since 15 July 2020, connection on 25 July 2020. URL : http://journals.openedition.org/ jso/8242 ; DOI : https://doi.org/10.4000/jso.8242

(c) Tous droits réservés 


\title{
Material culture of the Upper Sepik
}

by

\author{
Barry CRAIG
}

\begin{abstract}
Attempts have been made to map the style areas of the Sepik River region of Papua New Guinea. These were based on the (art) style of the most prominent carved and painted works. While this has, in the past, provided a framework for discussing the art of New Guinea and of the Sepik region in particular, it is no longer useful for research on the full range of material culture of Sepik peoples. Objects have been found in places quite far from where they were made, as a result of trade, warfare, intermarriage, migrations and flood, complicating the identification of local styles. Further, different kinds of objects have been variably subject to these effects and have different patterns of distribution. In this paper I examine the distribution of five kinds of artefacts to determine the boundaries of presencelabsence and distinct variations in those kinds of artefacts, in the Upper Sepik region from Ambunti to the West Papuan border. For reasons of convenience, ethnolinguistic groups are used as a proxy for provenance.
\end{abstract}

KeYwords: Upper Sepik, Border Mountains, material culture, style areas, ethno-linguistic groups

Attempts to map the style areas of the Sepik region (e.g. Bühler, 1960, Kaufmann in Greub, 1985 and in Peltier and Morin, 2006: 93) are usually based on the style of the carved and painted works that are the most prominent - masks: figures, suspension hooks, shields, slit gongs. Others have focussed on one kind of artefact and mapped out its distribution (e.g. Schmidt, 1929 and Haberland, 1963, 1965a, 1965b for Sepik

\section{RÉSUMÉ}

Bien des essais de cartographie des zones stylistiques de la région du Sepik ont été entrepris. Ces zones furent établies à partir du style (artistique) des sculptures et des ouvres peintes les plus remarquables. Bien que cela ait, dans le passé, établi un cadre afin de débattre sur l'art de la Nouvelle-Guinée et plus particulièrement de la région du Sepik, ce cadre n'est plus utile à la recherche si l'on prend en considération l'entièreté de la culture matérielle des sociétés du Sepik. Lidentification de ces styles se compliquait du fait que des objets furent trouvés très loin de leurs lieux de création suite à des échanges, des guerres, des intermariages, des migrations et des inondations. De plus, plusieurs sortes d'objets, soumis variablement à ces effets, connurent des formes différentes de distribution. Dans cet article, jexamine la répartition de cing sortes d'objets afin de déterminer leurs présences - ou leurs absences - ainsi que leurs variations propres dans une zone allant de la région d'Ambunti à la frontière de la Papouasie occidentale. Pour des raisons de facilité, les noms des groupes linguistiques sont utilisés pour désigner les provenances.

Mots-CLÉs : Haut Sepik, région frontalière des montagnes, culture matérielle, régions stylistiques, groupes ethno-linguistiques

shields; Hauser-Schäublin, 1989: part 2 for cult houses; Tiesler, 1970 for shields of the North Coast and 1984 for cuirasses).

Bühler's 1960 map indicates six art provinces. ${ }^{1}$ He puts the Kwoma, Nukuma and Mayo area with the Manambu, Iatmul and Sawos (Province II); upstream from there to the May River is Province III; and from Yellow River west is Province IV. He ignores the middle reaches of the

1. Here I refer only to those Sepik "art provinces" relevant to this paper (ie. II, III, IV).

* Formerly South Australian Museum; now barry.anthro@gmail.com 
southern tributaries - Frieda, Leonhard Schultze ${ }^{2}$, Wogamush and April rivers. Haberland (1965b: 46) draws a line east of the North River to include the riverine Abau with the Mountain Ok of central New Guinea but combines the Yellow/ Sand River area with the May River downstream to Swagup and the middle reaches of the southern tributaries. ${ }^{3}$

Kaufmann (1985: Map 5) recognises an overlap of Kwoma and Iatmul styles for the Manambu; includes the Ngala, Wogamush (Swagup), Iwam, Namie (Lujere) of Yellow River, and the Abau in one style region; groups the upper Sepik southern tributaries with the West Range; and the Border Mountains are included with the Bewani and Torricelli mountains. He does, however, suggest local styles within the larger regional styles, eg. he recognises the differences between the Ngala, Wogamush, Iwam and Lujere/Abau local styles.

But Kaufmann's map in Peltier and Morin (2006: 93), following his 1985 regional styles map and Kaeppler, Kaufmann and Newton, 1993, combines the Abau and Namie (Lujere) with the Iwam and other groups downstream as far as Swagup (Upper Sepik, style area 6), includes the West Range with the southern tributaries as style area 7, and the Border Mountains with the Bewani and Torricelli mountains as style area $2 .{ }^{4}$ However, in the context of that 1985 project, these broad style regions are merely

"a provisional form of arrangement... intended to transform apparent chaos into comprehensible organisation." (Kaufmann, 1985: 37)

Style area and art province are often used synonymously, which begs the question of what art is and what kinds of objects and activities fall into that category. These terms served the purpose for broad-brush analyses of former times but fail to capture the richness of human culture represented by a wider range of material objects. This does not mean that the concept of style is of no use - rather, that it should be reserved for discussion of particular kinds of objects or activities and not used to categorise and map entire cultures or groups of cultures. The exhibition Tanz der Ah- $n e n^{5}$ in Berlin 2015 unapologetically focuses on certain Sepik objects as art but categorises them according to functionality and cultural context, avoiding the style area approach.

In this paper I will consider several kinds of artefacts of the peoples of the Sepik River and adjacent areas between Ambunti and the West Papuan border, using the names of ethno-linguistic groups as a proxy for provenance, as several objects do not have a more specific provenance. ${ }^{6}$ I shall restrict my choice to slit gongs, trumpets, shields, paintings on sago palm petioles, and phallocrypts, while other groups of artefacts such as hand drums, canoe prows and canoe prow shields, lime containers and houses are set aside for reasons of space. ${ }^{7}$ I want to show that the boundaries of the so-called style areas shift depending on the kind of artefact being examined, i.e. that for phallocrypts and their sub-types or for shields and their sub-types, to name just two examples, different patterns of distribution can be identified. It can therefore be concluded that the concept of generalised (art) style areas is not useful.

Except for the Sepik upstream from May River (Craig, 1975; "Papers" and "Dataset" at www. uscngp.com), the data for upper Sepik material culture is scarce, partly because there are few publications, few museum collection datasets on-line, and physical access to museum collections is difficult. In 1968, 1969 and 1972-73, I photographed and collected artefacts for museums in Berlin, Leiden, Sydney, and Port Moresby. Although the number of objects I collected from May River downstream to Ambunti is relatively small and I do not have images of all of them, they expand the data beyond what has been published. ${ }^{8}$

There are two other limitations to the data. First, although there are pre-wwI collections, they are not fully published; most research and collecting in the upper Sepik area was carried out during the 1960s to 1980s, well after external factors began to affect upper Sepik societies and their material culture. Second, trade, warfare and so forth caused many artefacts to be collected at some distance from where they were made; this information was rarely recorded by collectors.

2. Schultze Jena's first name is spelt "Leonhard" and correctly on German maps, but the river is misspelt on modern maps as "Leonard Schultze".

3. Haberland was misled by faulty documentation of the collector C.M.A. Groenevelt. None of the objects illustrated by Abb. 2-12 are from Yellow River.

4. Again, I refer only to those Sepik style areas relevant to this paper (ie. 2, 6, 7).

5. The same exhibition was shown in Zürich and Paris 2015, see Peltier et al., 2015.

6. In this survey I include the Sawiyanoo of the West Range (all information courtesy Phillip Guddemi, personal communication, April 2017) and the Border Mountains groups but omit reference to the middle reaches of the Frieda, Leonhard Schultze and Wogamush rivers as there is almost no available data on the material culture of those areas except for shields. In the literature and on maps, spellings and names for settlements vary. I use the spellings and names in Laycock, 1973 in my text but retain authors' spellings when quoting them.

7. An addendum to this paper, dealing with these kinds of artefacts, will be found at www.uscngp.com/papers/.

8. A significant impediment for this paper on material culture (essentially visual material), is the limited number of illustrations allowed. This will require me to make numerous references to published examples which will be tedious for the intrepid reader to follow. For this I apologise. 


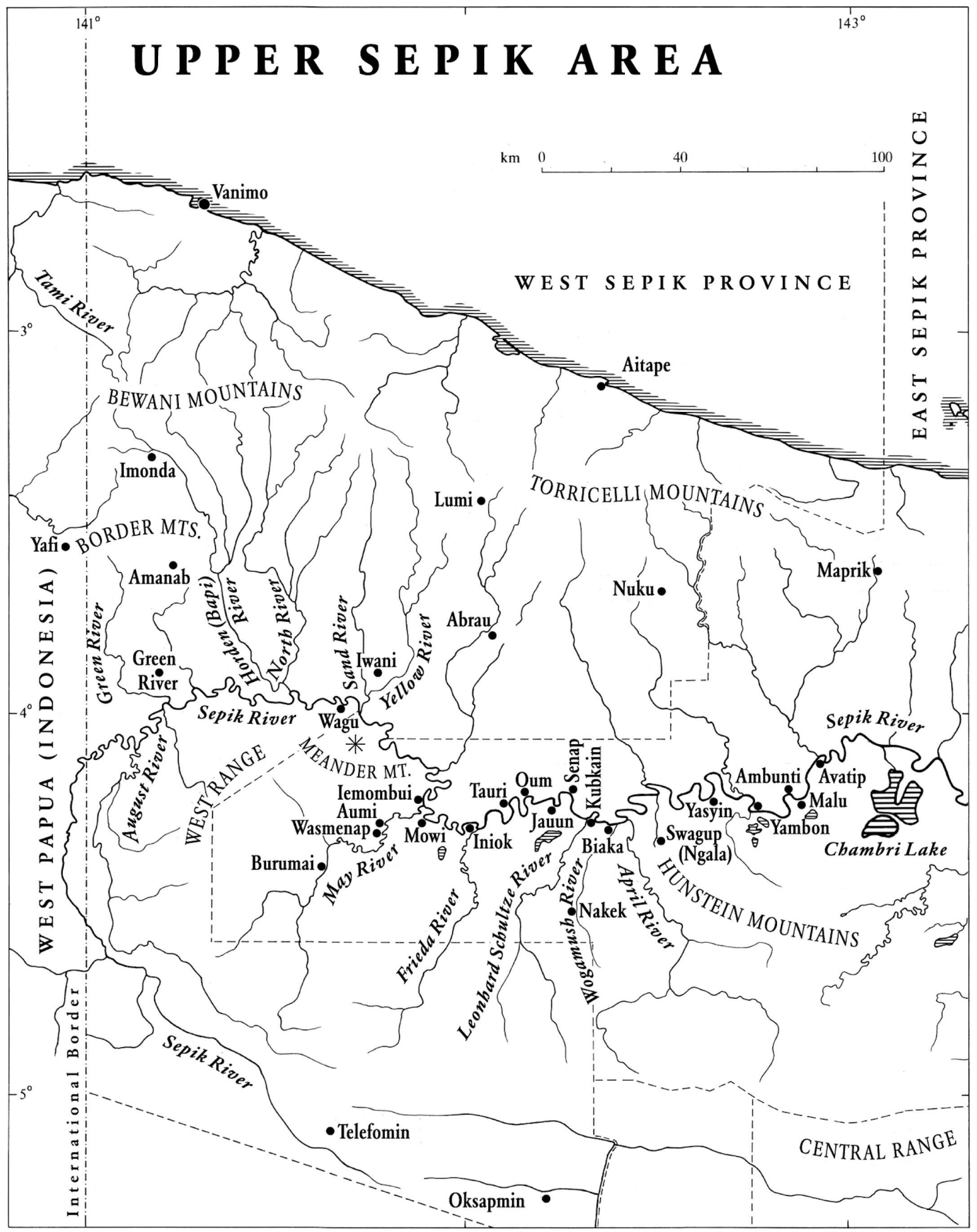

MAP 1. - Upper Sepik Area. This map overlaps in its eastern, i.e. Middle Sepik part with the general map of language groups (p.10) (Map drafts Courtesy of Oceania department, Museum der Kulturen Basel, final version drawn by Rudolf Zimmermann, Basel)

\section{The Linguistic Situation}

To what extent do the lines marking the boundaries of discontinuities (and conversely of shared characteristics) reflect the distribution of languages? A summary of the linguistic situation is needed.
Laycock $(1973,1975)$ mapped the languages of the Sepik-Ramu Region and set out his version of their genetic relationships. Most of the region west of the Karawari River, north and south of the Sepik, he allocated to the Sepik Sub-phylum with a separate Leonhard Schultze Sub-Phylum-level Family, a Left May Phylum in the West Range, a Kwomtari Phylum on the upper North 


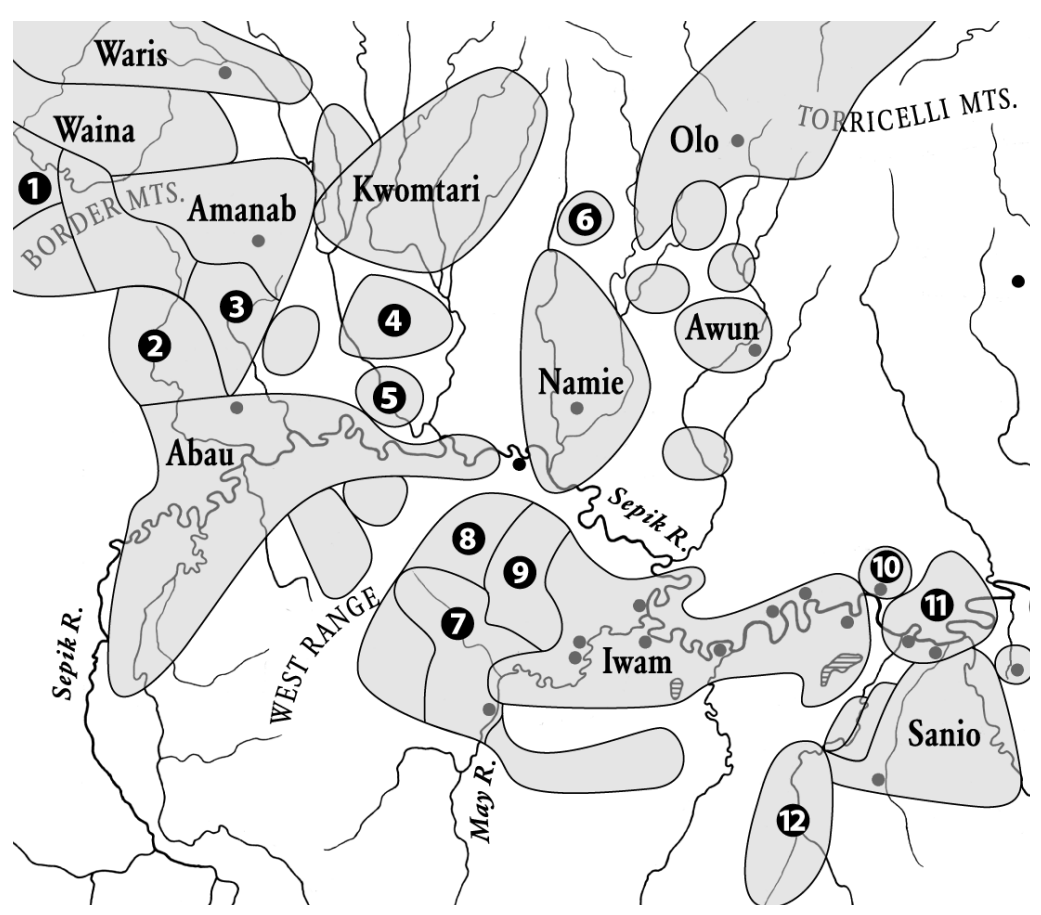

MAP 2. - Language groups in the Upper Sepik area (Map draft by Barry Craig, final version drawn by Rudolf Zimmermann, Basel). Identified are groups of speakers referred to in the text by B. Craig; the map shows either the language name according to Laycock, 1975, or one of the following numbers: 1: Yafi; 2: Yuri; 3: Anggor; 4: Nagatman; 5: Busa; 6: Ak; 7: Awai; 8: Warumoi; 9: Sawiyanoo; 10: Chenapien; 11: Wogamusin; 12: Yabio

\section{Slit gongs}

Slit gongs are found among almost all the societies of the Sepik-Ramu (Niles, 1983: Map 1). I have published a liberally-illustrated survey of slit gongs (Craig, 2016) so here I will summarise the information for the upper Sepik. Although the Abau of the Idam Valley mention slit gongs in their legends (Craig, 1980b: 63, 66, 67, 75, 82, $86)$, I saw only a couple of small, poorly-carved examples. The slit gongs of the North, Sand, Yellow and May rivers were consistent in form: a sharp, projecting prow with a truncated stern and minimal, if any, carved design. The Sawiyanoo slit gongs appeared to have been crudely carved versions of the May River Iwam slit gong and had no decorative carving.

Further downriver, slit gongs were similar in form to

River, Trans-New Guinea languages in the Border Mountains, and several Isolate languages north and south of the Abau. The region is linguistically heterogeneous.

Foley (2005) has critiqued Laycock's conclusions as based on inadequate data and divides the Sepik-Ramu Phylum languages into two genetically unrelated families - Sepik and Lower Sepik-Ramu - but appears to accept, more-orless, Laycock's Family divisions within his Sepik Sub-phylum.

Aikhenvald (2008: 595-6; 2011: 8, 55 endnotes 3,4$)$ has called into question aspects of the genetics of Sepik languages as outlined by both Laycock and Foley. Whereas the latter two researchers group the Abau, Iwam, Chenapian and Wogamusin languages into an Upper Sepik Stock, Aikhenvald prefers to regard them as genetically separate families or isolates, pending more rigorous comparative analysis.

Be that as it may, the genetic relationships among the languages between Ambunti and the International Border are not at issue in this paper. Rather, language is used simply as a proxy for provenance, at a level above that of settlement, because a significant number of objects lack more specific collection data. As indicated above, I shall restrict my analysis to slit gongs, trumpets, shields, paintings on sago palm petioles, and phallocrypts. those of the Iwam and upper Sepik basin: extended prows, often with a hole to facilitate hauling, and truncated sterns; but they differed in having a prow at least half the length of the whole gong and expertly carved with human, animal or other motifs of clan totemic significance. The slit gongs of these peoples were associated with water or bush spirits, used during male initiation and in celebration of successful head hunting, and were symbolic of canoes. Within this commonality of form and significance, each ethno-linguistic group had its own style of carved prows.

There is a marked change in the form of Manambu slit gongs: they were shorter, with elaborately carved prows (in the form of a crocodile's head) and a truncated stern. This kind was found next east among the western Iatmul where the prow was carved in various human and animal forms and the truncated stern had a small projecting ancestral face or totem animal.

There were therefore three kinds of upper Sepik slit gongs, with boundaries between the Manambu and the Kwoma, and between the Wogamusin and the Iwam.

\section{Trumpets}

Wood trumpets were used as musical instruments and/or as signalling devices declaring victory in a 


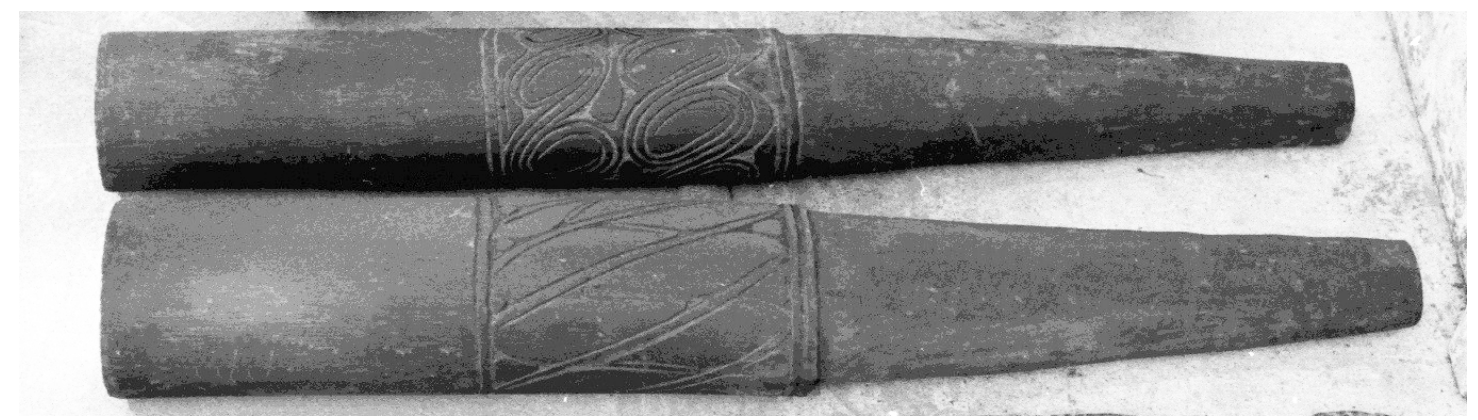

Figure 1. - Trumpets (geik) collected at Buremai, May River Iwam, in 1972. Top to bottom: PNGNM 79.1.526, 527 (C) B. Craig: 1972-73, BM25:27)

raid or battle. In the Border Mountains, orchestras of plain, wood end-blown trumpets were made in several sizes, each with its own tone, from quite small to large bass trumpets c. $150 \mathrm{~cm}$ long (Juillerat, 1992: plates 13, 14). These were played in association with certain rituals.

Elsewhere it appears that the trumpets were for signalling success in warfare but also to accompany hand drums (e.g. Newton, 1971: 53). The Abau end-blown trumpets were carved with designs at the distal end that are like the designs on their hand drums (Craig, 1975: 424; Kelm, 1966: plates 222, 231; Swadling et al., 1988: plate 242). ${ }^{9}$ Two May River Iwam end-blown trumpets I photographed in 1972 (fig. 1) were carved with incised curvilinear designs in a band around the middle whereas the incised designs on two trumpets from "Jauun" (Yauenian, Sepik River Iwam), collected in 1912/13, cover about two-thirds of the body of the trumpet (Kelm, 1966: plates 194, 195).

Guddemi photographed a plain Sawiyanoo trumpet and two with carved and painted designs. One design is similar to the design on one of the Sawiyanoo hand drums (alternating triangles) and the other is like certain carved designs on arrow foreshafts of the upper Sepik basin.

Wogamusin trumpets were similar to those of the Iwam (Kelm, 1966: plate 141; Newton, 1971: fig. 106) but the incised designs resemble the face designs on Wogamusin shields (cf. ibid.: fig. 107; Kelm, 1966: plates 136-140). The Ngala blew short bamboo trumpets (mohub), imitating cassowary calls, to celebrate a successful raid (Newton, 1971: 36); the Kwoma/Nukuma apparently used large Triton shell trumpets (Newton, 1971: 83) as well as wood trumpets (Bowden, 1983: 78).

Manambu trumpets (Kelm, 1966: plate 3) were like those of the Iatmul: side-blown, with a carved animal form at the proximal end and incised curvilinear designs on the body of the instrument.

There were therefore several kinds of trumpets in the upper Sepik region; the side-blown wood trumpets of the Manambu and Iatmul differed radically from the end-blown bamboo trumpets of the Ngala and the wood trumpets of the Wogamusin and Iwam. The end-blown trumpets of the Namie were plainer than those of the Abau and Sawiyanoo, which were carved and painted at the distal end with designs like those on their hand drums. The Border Mountains trumpets were plain and made as musical instruments in a set of different sizes.

\section{Shields}

The Border Mountains people did not have shields; they relied on woven rattan cuirasses for protection (Tiesler, 1984). From the Abau in the west to the Kwoma and Manambu in the east, there were basically three kinds of shields: wood shields slung on the shoulder and used with bows and arrows, wood shields held by the forearm and used with spears, and animal hide shields used with both kinds of weapons.

\section{Wood shields used with bows and arrows}

The peoples of the upper Sepik basin - the Abau, the Busa and Nagatman of the Lower Horden (Bapi) River, the Kwomtari of the upper North River, and the Namie (Lujere), Ak and Awun of the Sand and Yellow Rivers - all used bows and arrows in warfare and their shields were large, relatively light, flat boards carried on the shoulder of the bow-arm. There is a consistency of style in the mostly bilaterally symmetrical designs on these shields, carved as non-representational, curvilinear relief bands painted black against a white and red or orange-coloured ground (Beran and Craig, 2005: figs 4.1-4.6, 4.8; Craig, 1975: figs 10-32; Haberland, 1963: Tafel rv, Nrs 1, 2; Kelm, 1966: plates 197-220; search www.uscngp.com/dataset/). Designs such as those on the Namie and Abau shields illustrated by Kelm (1966: plates

9. William Mitchell photographed a plain wood trumpet at an Iwani hamlet (Namie) in 1972, almost identical to the Abau trumpet in Kelm, 1966: plate 230. I collected one (wungwani) at the Namie village, Bapi, in 1969, like the one in Kelm, 1966, that was carved for a third of the distal end with a cursory unpainted design (Berlin VI 50156). 
197-201, 206, 207, 209), with in-curving and out-curving pairs of spirals, are found throughout the upper Sepik basin.

The designs on some of the Namie shields are remarkably similar to certain designs on sago palm petioles of the West Range (the Warumoi - Schuster, 1969: plates 35-39; and the Sawiyanoo - Guddemi, 1993: fig. 10 left; 2012: fig. 10). ${ }^{10}$

The designs on the shields of the Abau and other upper Sepik basin peoples did not appear to have any particular significance, certainly not as totems or heraldic of kin groups. I disagree with Benitez and Barbier (2000: 190) that the "face" design is to be found on shields of the Namie and Abau. However, a few shields carved for sale in the 1960s included representations of anthropomorphic spirits, fish, reptiles and so forth, not found on the earliest collected shields. ${ }^{11}$

\section{Wood shields used with spears}

The May River and Sepik Iwam, downstream to the Kwoma and Manambu, primarily used spears for warfare but warriors without shields may have used either spears or bows and arrows. Their shields were relatively thick, narrow, tall and held at the rear with the forearm by a rigid handle secured to two vertical ridges cut from the wood of the rear of the shield (Beran and Craig, 2005: figs 4.9, 4.10, 4.20; Haberland, 1963: abb. 10-16) or to two vertical bars secured through holes in the shield (Beran and Craig, 2005: fig. 4.19). The front of these shields was usually carved with a slight central vertical ridge. The design was carved as relief bands painted black against a white, yellow and red ground.

The handles at the rear of the usually unpigmented Kwoma and Manambu shields were made of a hoop of thick rattan fastened through four pairs of holes, with two crosspieces attached (Haberland, 1963: abb. 3-6).

Traditional Iwam shield designs, bilaterally symmetrical, were often carved as two, three or more horizontal panels of spiral and leaf-like motifs that are not obviously representational (Haberland, 1963, Tafel III; 1965b, Abb. 10-15; Kelm, 1966: plate 188; Schuster, 1969: figs 15-21). Schuster (1969: 12, 13) detects an imperfect relationship between particular named design motifs and clan totems.

The designs of Iwam shields carved for sale in the 1960s sometimes incorporated animal and anthropomorphic motifs (Abramson, 1970) but it is unlikely that this was the case previously. In 1972, I photographed shields carved for sale at the Sepik
River Iwam village of Oum incorporating the typical Wogamusin face design identified at Oum as local culture heroes Taum and Agyenelo; it is not certain this would have been the case previously.

Wogamusin shields, usually with designs symmetrical around the vertical axis only, were wider than Iwam shields and one of the multiplicity of designs was clearly a human face (Beran and Craig, 2005: fig. 4.19; Newton, 1971: fig. 107 and 1975: fig. 17; Haberland, 1965b: abb. 8, 9; Kelm, 1966: plates 136-138, 140; Newton, 1975: fig. 9) representing the culture hero Wulruwiyanggwat (Newton, 1975: 209). Other design elements represented certain natural objects that were

"properties of the various clans... The designs, as a whole, and probably especially the clusters of signs on the shields, were then heraldic, and presumably functioned as statements of clan unity." (Newton, 1975: 206)

The design on certain Wogamusin shields, closely resembling an Ngala shield design, was identified by Newton's informants as belonging to the Kubru (Kubkain) clan Yino, whose ancestors were Ngala (Newton, 1975: 202 \& figs 3-5). ${ }^{12}$ However, the so-called face design of the Ngala is less convincing than the Wulruwiyanggwət face design of the Wogamusin (Kelm, 1966: plates 166, 167; Newton, 1971: fig. 86; Beran and Craig, 2005: fig.4.20). Some Wogamusin shield designs occupy only the top half of the front of the shield (Kelm, 1966: plate 157; Newton, 1975: figs 12, 15).

Three shields captioned "April River" (Kelm, 1966: plates 157-159) are quite different to one another. The exact locations where they were collected is uncertain. $\mathrm{Nr} 157$ has been assigned a "Kubru" (Wogamusin) origin by Newton (1975: fig. 6) and may have been collected near the April-Sepik junction, Wogamusin territory. $\mathrm{Nr} 158$ more comfortably sits with Sepik River Iwam shields (e.g. Kelm, 1966: plate 186 from "Jauun"). Nr 159 is most likely a Sanio shield, by comparison with a Sanio shield from Nakek on the Wogamush River with similar motifs that I photographed in the collection of Wayne Heathcote in December 1972. The 1912-13 German expedition went up the Leonhard Schultze, past its Sanio settlements, as far as Yabio territory.

Ngala shield designs were bilaterally symmetrical, which was also the case with certain Wogamusin designs (Newton, 1975: figs 3-5). Newton states that Ngala shields

10. In turn, certain petiole paintings of the Awai of the West Range (Schuster, 1969: plates 23-27) are remarkably similar to the designs on shields of central New Guinea (Craig, 1988).

11. Possibly influenced by the designs on Sawiyanoo petiole paintings ( $c f$. Guddemi, 2012) and/or the designs on Border Mountains petiole masks.

12. Newton's Ngala and Wogamusin informants (1995: 231) agreed that Wogamusin shields were based on Ngala models. 
"were identified with major ancestral spirits, some of them at least water-spirits" (Newton, 1971: 36)

The narrower "Kara" (= Swagup or Ngala) shield in Kelm (1966: plate 168) seems unrelated to the other Ngala shields and more like certain Iwam shields (Kelm, 1966: plates 186, 187); the documentation is questionable, or the shield has been traded or captured in battle. Newton (1971: 33) notes trade relations between Ngala and "Senap" (Chenapien) and although no Senap shields have been published, they may have been like Yauenian (Sepik Iwam) shields (e.g. Kelm, 1966: plate 186).

The wood shields of the Kwoma and Manambu look so alike it would be difficult to make a distinction. The design was incised so that a minimum of the surface of the board was removed. There is a large central face with a wide nose and small mouth, and a net-like pattern at the top (Beran and Craig, 2005: fig. 4.21; Craig et al., 2015: figs 3.105-3.108; Haberland, 1963, Tafel I, Nrs 1-4; Kelm, 1966: plates 44-46; Newton, 1971: figs 125, 183). These are strictly two-dimensional versions of western Iatmul, slightly sculptural shields with a central face (Benitez and Barbier, 2000: 186-187; Beran and Craig, 2005: fig. 4.28; Craig et al., 2015: fig. 3.53). The Kwoma-Manambu shields are usually almost black all over whereas the western Iatmul shields are highly pigmented, but both kinds have the hoop of thick rattan at the rear for a handle.

\section{Animal hide shields}

Sawiyanoo shields were made of pig skin stretched over a rattan frame (Guddemi, 1992: 144), like those of the spear-using peoples between the Sepik and the Torricelli foothills (Craig et al., 2008: 255256). This is also documented for the Kwoma, Manambu, Mayo and Kwanga (Beran and Craig, 2005: 91: figs 4.22, 4.23; Craig et al., 2015: figs 3.109-3.115; Haberland, 1963: Tafel 1, Nrs 5-7 and abb. 7-9), who used pig, crocodile and, occasionally, cassowary hide shields in addition to their wood shields. The Kwoma required the most senior men to carry the wood shields; younger men, quicker on their feet, used the animal-hide shields (Kaufmann: pers. comm. 28 Feb. 2017; Newton, 1971: 88).

Summarising, upper Sepik wood shields were of two basic kinds. In the upper Sepik basin, broad, flat and light carried on the shoulder, used with bows and arrows, and there was a consistency in the designs throughout the area. From May River downstream, the shields were relatively narrow, tall, thick and heavy, with rigid handles and used with spears. There was a clear distinction in designs between the Iwam and the Wogamusin, and between the Ngala and the Kwoma-Manambu. Animal hide shields were used in the West Range and by the Kwoma and Nukuma.

\section{Paintings on sago petioles}

Throughout the Sepik region, men painted on sago petioles, the flattened base of the sago palm frond. Petioles could be tied together to form one large surface, such as for the painted façades of Abelam or Kambot ceremonial houses (Craig, 2010a: 52, MPNr 4, and Fig. 50); or individually fastened en masse to the ceiling of a Kwoma ceremonial house (Bowden, 2006: 5), Torricelli Mountains men's house (Craig, 2012: figs 10, 12 right), or to the walls and ceilings of men's houses of the May River Iwam and West Range Awai, Sawiyanoo and Warumoi (Guddemi, 1992, 1993, 2012; Schuster, 1969). Painted petioles also formed components of masks, canoe prow "shields", skull racks, and so forth.

In the upper Sepik basin - from Yellow River west to, and including, the Border Mountains masks were worn in ceremonies for curing illness, for funerals (Peter, 1990: 248) and for the fertility of the sago palm. The basic mask was a sub-conical frame with painted petioles tied on each side (see Craig, 1975: fig.3; 1980a: plates 38-43). These masks, called yafi $i^{13}$ by the Abau (Craig, 1980a: 26-27) and na wowi by the Namie (Mitchell, 1975: plate 7), were fringed with a fibre skirt and decorated with plant materials and feathers. The painted designs (Kelm, 1966: plates 232-238) are consistent with, and as varied as, the designs on their shields and do not appear to have had any generally accepted meanings.

While some of the designs on the masks of the Waina, Amanab, Anggor, Yuri and Yafi of the Border Mountains are almost identical to those of the Abau and Namie, most are different, and many include representations of animals and other creatures. As Huber observes, the peoples of the Border Mountains

"participate in a system of regional communication such that each is implicated in the past of the oth$\mathrm{er}[\mathrm{s}]$, and a level must exist at which they are speaking related symbolic languages." (Huber, 1990: 158)

13. It may not be coincidence that similar masks, the painted petioles of which were called "sickness shields" by K.W. Galis in 1956, were photographed among the Yafi, south-western neighbours of the Waina-Sowanda of the Border Mountains (Hoogerbrugge, 1995: figs 43, 44 \& plate 14). The designs on the two masks in Fig. 43 are consistent with Abau, Namie, Ak, Awun and Kwomtari shield designs (Kelm and Kelm, 1980: plate 29). Almost the same design was painted on a Gargar (Yuri) "Tanzbrett" (Hermann et al., 1996: abb. 14) and on masks of the Amanab and Anggor (www.uscngp.com/dataset/). Among the Sawiyanoo, the term yafi designates sacred and powerful things or people "which have great potential to help or harm those who come in contact with them" (Guddemi, 1992: 7). 
It is likely that the Kwomtari, and the Olo (Wape) of the western Torricelli Mountains, also were part of this system.

The Kwomtari made three kinds of masks: the painted sago petiole masks (rukagwa) with panels about a metre high; painted coconut fibre masks (iavro) about 1.5 metres high; and large painted bark cloth masks (ariaso) about 3 metres high. These masks often incorporated an animal representation at the centre (see USCNGP Dataset; Craig, 2010a: 205-206 and fig. 95).

There is a remarkable similarity between the Abau and Namie designs on the one hand and the men's house petiole painting designs of the Sawiyanoo and Warumoi of the West Range (Guddemi, 1993, 2012; Schuster, 1969: figs 28-39) on the other, where the designs were not interpreted as a whole but individual motifs were named and had mythical significance. For the West Range communities, the act of painting, by evoking the "guardians" of game animals, was linked to success in hunting (Guddemi, 2012: 32; cf. Kaufmann, 2003: 22-23 for the upper Karawari).

The May River Iwam produced petiole paintings to line the walls of their men's houses, incorporating motifs common on their shields (Kelm, 1966: plates 183-185; Schuster, 1969: plates 5-12). These motifs were considered by Schuster to have clan-specific significance linked to certain myths (1969: 11, 12).

I have not found any published examples of painted petioles from the Sepik River Iwam, but since the May River Iwam produced them, and all the Iwam and Chenapian settlements had the conical-roofed men's houses (Hauser-Schäublin, 1989: 443 , Abb. 183, 185, 186), it is likely that the Sepik Iwam and the Chenapian produced them also.

Newton reports that the porches of both Ngala and Wogamusin ceremonial houses were decorated with painted sago petioles (1971: 34, 51 \& Fig. 69; 2015, Abb. 24). A petiole said to be from April River (Kelm, 1968: plate 529), most likely Wogamusin, has been painted with a "winged" design similar to that on an Ngala staff illustrated by Newton (1971: fig. 85). A photograph of what are likely to be Kubkain canoes seeking trade with an Australian military expedition up the Sepik in 1914 shows a painted petiole in one of the canoes (Craig and Winter, 2016: fig. 24); the design is consistent with an April River (Wogamusin) shield design (Kelm, 1966: plate 157) and 1970s Kubkain carved and painted boards (Craig and Winter, 2016: fig. 25). From the sparse data available, it appears that the designs on Ngala petioles were similar to those of the Wogamusin but both were different to those on Iwam petioles.

The Mayo, Kwoma and Nukuma decorated the ceilings of their cult houses with sago petiole paintings (Bowden, 1983: plates 2-4; 2006; Kaufmann, 1979: figs $18-5,18-17$ to $18-21,18-27$; Newton, 1971: figs 136-140, 175). Although the petiole paintings of these peoples are alike, and most are different from those of the peoples upstream, Bowden states that the painting style of the Kwoma "differs in important ways" from that of the Nukuma and Mayo (2006: 2).

The images painted by the Kwoma depict the clan totems (animals, plants, and so forth) of the painters. Some designs may look alike but depict different totems - the painter has to be asked what is being depicted (e.g. Bowden, 2006: plates 2.6 and 2.10 second from left). Thus Bowden describes the designs as non-figurative or abstract but nevertheless representational (Bowden, 2006: $11,14,16-21)$, and some designs bear some resemblance to the entities they depict, e.g. flying fox (Bowden, 2006: plates 6.2, 8.4, 9.1, 10.2), a taro plant (Plate 10.38), anthropomorphised representations of various spirits (plates 6.11, 10.41) or shooting stars (plates 6.5, 6.6). The faces of the Kwoma petiole designs have the large circular eyes, fat nose and open, up-curving mouth of the Kwoma and Manambu shields and are similar to the faces on the Wogamusin shields (Bowden, 2006: plates 2.5, 10.35, cf. Kelm, 1966: plates 136-138, 140; Newton, 1971: fig. 107).

Newton mentions that for the meiurr ritual of the Manambu, the walls of the ground floor of the ceremonial house were decorated with bark paintings (Newton, 1971: 68) but I have not located any published examples. Perhaps they were similar to Kwoma paintings.

In the upper Sepik region, from the Kwoma to the May River and West Range, the designs painted on the sago palm petioles for the men's houses were consistent with the designs on the shields. As for the shields, each ethno-linguistic group had its own distinctive graphic style.

From the Yellow River, upstream and in the Border Mountains, the paintings were incorporated into masks, each ethno-linguistic group with its own distinctive style of painted design, but with a few particular designs, also found on shields, common across the whole of the upper Sepik basin from the Yafi of the Border Mountains as far east as the Sawiyanoo of the West Range.

\section{Phallocrypts}

Alfred Gell (1971) analyses the significance of penis-sheathing among the Umeda (Waina-Sowanda) of the Border Mountains immediately south of Imonda. His map (Gell, 1971: fig. 1) indicates that phallocrypts of the north coast of West Papua and the western half of the north coast of the Sepik provinces, inland to the southern fall of the Bewani Mountains, were globular gourds and south of that were elongated gourd sheaths. 

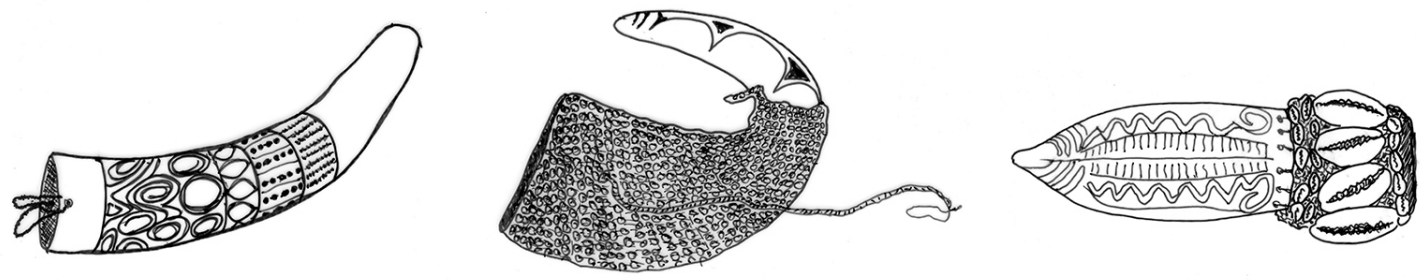

Figure 2. - Left: Gourd phallocrypt (makeit) from Wasmenap village, May River IWAM, 1972. PNGnM 79.1.215. Centre: Gourd phallocrypt (simukwasa), with lizard skin cover, from Oum village, Sepik River IWAM, 1973. PNGNM 79.1.234. Right: Coconut shell phallocrypt (simuwa), with cowrie and nassa shells, from Oum village Sepik River IWAM, 1973. PNGNM 79.1.258 (Sketches by B. Craig)

However, this is over-simplified. Along the north coast, the shape was oval with the short neck of the gourd worn upwards by having the hole for the penis in the side of the gourd (Preuss, 1899, Tafel vi, 1-8; Schultze Jena, 1914: Tafel xxiI, 1, 3; xxIv, 1, and xxL; van der Sande, 1907: plate Xv, $4,5)$. Further inland on the headwaters of the Tami, the gourd was larger, oval and worn hanging downwards as the hole was at the fatter end of the gourd (Preuss, 1899: Tafel vi, 34-36; Schultze Jena, 1914: Tafel xxiII, 1, 2; Tafel xuI, a-c). Both kinds of gourds were pyro-engraved with curvilinear and figurative motifs.

Immediately south of the Bewanis, among the Waris and Waina, the everyday gourd (peda) was egg-shaped with curvilinear pyro-engraved designs (Gell, 1971: fig. 3B). Here, there was another kind of gourd phallocrypt (pedasub), worn for ceremonial purposes, which was larger, eggshaped, smoke-blackened and without designs (Gell, 1971: fig. 3A).

The Amanab used the same kind of large ceremonial phallocrypt (su-wagmu) as the Waina (Juillerat, 1992: plate 5) but the everyday phallocrypt (biakun) with pyro-engraved designs included both the tapering, straight or curly gourd and the smaller egg-shaped gourd (see www.uscngp.com/dataset/).

The Kwomtari ceremonial phallocrypts (ierif$d u$ ) were quite long, c. $50 \mathrm{~cm}$, some with pyro-engraved designs and some undecorated. This kind was used also among the Abau (yapsiau: Craig, 1980a: plate 18) and the Namie (tame: Mitchell, 1975: plates 7, 8; see Kelm and Kelm, 1980: fig. 35 for an Awun example). These were danced during sickness-curing ceremonies while wearing yafilna wowi masks. The long phallocrypts were made to swing upwards and clack on a belt of animal bones and large seeds (eg. Craig and Winter, 2016: fig. 83c; Schultze Jena, 1914: Tafel XLIII, c: from Dorf 30 [Wagu, an Abau settlement]).

Everyday gourd phallocrypts of the Abau (siau) were relatively long $($ c. $15-30 \mathrm{~cm})$, straight or curling, and without designs (Craig and Winter, 2016: figs 39, 42; Schultze Jena, 1914: Tafel XLI, $\mathrm{d}, \mathrm{h}, \mathrm{l}, \mathrm{m})$. The egg-shaped: pyro-engraved gourd of the Border Mountains was not seen by Schultze Jena or Thurnwald among the Abau in the early $20^{\text {th }}$ century but it was common by the $1960 \mathrm{~s}$ (Craig, 1980a: 18-20); ${ }^{14}$ it was not adopted by the Namie, who used the pyro-engraved straight tapering or curly gourd (waifam/waibamu, Craig and Winter, 2016: fig. 85b) or by the Awun east of the Namie (woipami, Kelm and Kelm, 1980: fig. 34). The Abau and Namie occasionally used the shell of the immature coconut, called dilonau by the Namie, and worn only by old men (Craig and Winter, 2016: figs 35, 36; Kelm, 1968: plate 538; Schultze Jena, 1914: Tafel xuI, e, g).

Sawiyanoo men wore both straight and curling gourd phallocrypts $(l o:)$ with the same pyro-engraved designs as for the Namie phallocrypts; the coconut-shell phallocrypt (molo lo:) was worn by older men.

I saw and collected only one phallocrypt (makeit - PNGNM 79.1.215) on the May River, in 1972. It is a curving tapered gourd with both etched and pyro-engraved designs (fig. 2, left). The vendor said that it was the usual phallocrypt for men of the May River Iwam but Kelm illustrates a May River bamboo tube phallocrypt (1968: plate 533), suggesting that there may have been distinctions based on grade of initiation or social status.

At the Sepik Iwam village of Oum, I collected a curved gourd phallocrypt (simukwasa - PNGNM 79.1.234) with a pyro-engraved design like those of the Namie (fig. 2, centre), and a decorated coconut shell phallocrypt (simuwa - PNGNM 79.1.258) like those of the Wogamusin (fig. 2, right). I was told that the gourd phallocrypts were worn by youths going into the spirit house for the first time and that the coconut shell phallocrypts were worn by homicides. Both these examples had been made by the middle-aged vendors' fathers.

Among the Wogamusin, there were three kinds of phallocrypt: the long tapering plaited tube, a

14. This suggests that the control of warfare and consequent freedom to travel encouraged the adoption of "foreign" fashions in men's wear. 
length of bamboo with a simple pyro-engraved design, and the immature coconut shell with etched design and nassa shell decoration (Kelm, 1966: plate 160; Kelm, 1968: plates 535, 537; Newton, 1971: figs 102, 103; Schultze Jena, 1914: Tafel XLI, i, k). Newton records that at first initiation, the lads are called Tumbul and are given the plaited phallocrypt by their fathers. At their next initiation, young men of marriageable age were called Löl'iyan and given the bamboo phallocrypt to wear. Once a man killed an enemy, he entered the third and highest grade, Komaptam, and was given the engraved coconut shell phallocrypt to wear (Newton, 1971: 52-54).

It would appear from Newton's information that there was an initiation for Ngala lads at the conclusion of which they could wear

"various types of penis covers, including basketry or bamboo tubes and flying fox wings." (Newton, 1971: 35)

As for the Wogamusin, after an Ngala man had killed an enemy, he wore a coconut shell phallocrypt (Newton, 1971: 36).

The Manambu had shell- and feather-decorated phallocrypts of bamboo or gourd (Kelm, 1968: plates 534,536$)$ that were presented to youths after the scarification ceremony called Wa'ar mba'angkwa (Newton, 1971: 67). Flying fox skin aprons signified that a man was a homicide (Newton, 1971: 71). Kwoma men were entirely naked but after youths had passed through the hande sukwia initiations, they were given bamboo phallocrypts to wear, which were later removed

"and put on palm tree sprouts, which broke them as they grew." (Newton, 1971: 83)

Phallocrypts of various materials signified particular ritual grades for the youths and men of the upper Sepik as far upstream as the May River. Beyond there, there were three kinds: relatively small gourds for everyday wear; occasionally immature coconut shells for the older men; and large gourds used by masked performers for sickness curing and sago fertility. Within the category of everyday wear, some groups used globular gourds, others used straight or curly gourds which were usually decorated with pyro-engraved spiral designs. At some time between 1914 and the 1960s, the everyday globular gourd of the Border Mountains became popular among the Abau of the upper Sepik basin.

\section{Discussion}

This brief survey of five kinds of artefacts in most cases has been based on relatively few ex- amples and many of those examples have poor, some even incorrect, provenance. The following comments are therefore tentative until museums have fully digitised their collections, checked documentation, and made the images and documentation available on the Web so that more rigorous research can be undertaken.

Such research must recognise that even individual speech communities were by no means culturally homogeneous. Newton (1975) demonstrated how the designs on Wogamusin shields reflect the complex interactions and movements of peoples in an area ranging from the Hunstein Mountains to the May River (his diagram p.197). Similarly, it appears that the Ngala and Manambu communities also derive from a diversity of sources (Newton, 1971: 64 \& 1995; Aikhenvald, 2008: 22-24). Therefore, depending on the focus of analysis, the line signalling a discontinuity of form or function may separate neighbours who otherwise share a lot in common. Given these limitations, where are the boundaries between distinct kinds of artefacts in the region of the Sepik River, from Ambunti to the border with West Papua?

The Manambu, while sharing similar slit gongs and trumpets with the Iatmul, nevertheless had wood and animal skin shields identical with those of their immediate Kwoma neighbours (and traditional enemies). They believe their clans originated from mythical villages to the east and to the west (Harrison, 1990: 45-47).

The Wogamusin, strongly influenced by the Ngala, shared with the Iwam similar trumpets, two or three kinds of phallocrypts marking successive stages of male initiation or social status, and heavy arm-held wood shields used with spears, but the designs on these things differed between these ethno-linguistic groups. May River Iwam slit gongs were relatively crudely carved, like those in the upper Sepik basin (from the Yellow River upstream), whereas those downstream were expertly carved with elaborate designs characteristic of each ethno-linguistic group.

In the West Range and the upper Sepik basin, material culture characteristics change significantly, in particular the use of bows and arrows rather than spears in warfare, and the differences in the shields and their designs. From the West Range and the Iwam downstream, painted sago petioles were used in association with men's houses, but from Yellow River upstream were mask components. Most, but not all, of the designs on Border Mountains and Kwomtari masks differed from those of the Abau and Namie. Phallocrypts fashioned from gourds and immature coconuts were found among the Abau, Namie, Sawiyanoo and Iwam but gourds were not used further downstream except, heavily encrusted with shells, by the Manambu. Depending on the kind of artefact and variables of form and graphic design, boundaries may be drawn differently. 
The migration of ancestral groups may explain how the recent distribution of some of these kinds of objects have evolved. Thus, the Namie believe they migrated up the Sepik to their present location (Mitchell, 1975: 413). The Abau also held that they migrated upstream (from May River) to their present territory strung out along the Sepik, from above the Yellow River junction, to the Idam and August rivers and West Papuan border. These oral traditions, along with the distribution of languages, suggest that the Namie, Ak and Awun, pressured by the ancestors of the Iwam, moved up the Sepik to the Sand and Yellow rivers earlier than the Abau movement westwards. Had the Abau found the Yellow and Sand rivers uninhabited, they would most likely have settled there as it is more elevated and drier, and there are fewer mosquitoes than on the Sepik River. Instead they had to bypass the Namie and press on westwards.

It is not clear where the Namie and Abau were located prior to their migrations upstream but similarities with the graphic designs of the peoples of the West Range suggest somewhere in the vicinity of the middle May River, now occupied by the Iwam.

There is also abundant evidence of continuities in material culture across linguistic boundaries in the Sepik region through trade, marriage and warfare. To determine precise continuities and discontinuities in material culture, a much larger sample of objects with accurate provenance at the level of settlement would be required and the boundaries of the distributions of kinds of artefacts, or of particular characteristics of kinds of artefacts, could be drawn. This is at present only possible for the region west of the May River (see www.uscngp.com/dataset/).

A final observation concerns changes over a period of time. The suggestion has been made that rattan cuirasses of the north coast, Border Mountains and central New Guinea were inspired by Portuguese armour. Whether or not that was the case, Tiesler concludes that

"New Guinea cuirasses [are] a relatively new cultural feature originating only a few centuries ago." (Tiesler, 1984: 82)

There is a significant break in cuirass distribution between the Border Mountains and the central New Guinea Mountain Ok peoples. This may have been caused by the intrusion of shield-using Abau peoples westwards along the upper Sepik and provides an approximate sequence of events, with the distribution of cuirasses southwards from the Bewani and Border mountains pre-dating the arrival of the Abau into that western portion of the upper Sepik basin.

There seems to have been a diffusion of the yafi sickness masks and rituals throughout the upper Sepik basin originating among the Yafi across the Border north-west of the Yuri and transformed considerably by the Sawiyanoo of the West Range. Diffusion of cultural practices does not necessarily take a long time. The egg-shaped phallocrypts for everyday wear found in the Border Mountains do not appear to have existed among the Abau when Schultze Jena and Thurnwald took photographs there in 1910 and 1914; the Abau wore plain straight or curling gourds. By 1968, they were wearing eggshaped pyro-engraved phallocrypts as well. ${ }^{15}$

\section{Conclusion}

Whether or not any of these speculations will be supported by further data, it is clear that it is more useful to examine the nature and distribution of kinds of artefacts individually rather than lumping cultures into "style areas" based on one or two kinds of "art object" and, for the broader purpose of understanding human cultures, we should cease referring to "art" and consider the full range of material objects produced by people. This applies also to the non-material aspects of culture such as dance, music and song, oral traditions and so forth.

It would be unfair to assume that scholars who have used the concept of style regions necessarily think of culture in static, homogeneous terms. As Kaufmann has indicated, such a taxonomy is merely a convenience for making some initial sense of heterogeneous phenomena. But we now have the technology, if not readily accessible financial means, for providing the data (museum collections) in such a way that a more sophisticated taxonomy of material culture can be developed that will acknowledge the richness of human culture. Let's get started with whatever resources we have at hand (see Craig, 2010b).

\section{REFERENCES}

Abramson Jerry, 1970. The "Third Style" of Sepik River Art, Artforum Ix (3), pp. 54-57.

Aikhenvald Alexandra, 2008. The Manambu Language of East Sepik, Papua New Guinea, Oxford, Oxford University Press. 
Bateson Gregory, 1932. Social Structure of the Iatmul People of the Sepik River, Oceania 2, pp. 245-291, 401-453.

Behrmann Walter, 1922. Im Stromgebiet des Sepik, Berlin, August Scherl.

Benitez-Johannet Purissima and Jean-Paul Barbier, 2000. Shields: Africa, Southeast Asia and Oceania from the collections of the Barbier-Mueller Museum, Munich, London, New York, Prestel.

Beran Harry and Barry Craig (eds), 2005. Shields of Melanesia, Adelaide, Crawford House Publishing Australia.

Bowden Ross, 1983. Yena. Art and Ceremony in a Sepik Society, Oxford, Pitt Rivers Museum.

-, 2006. Creative Spirits. Bark Painting in the Washkuk Hills of North New Guinea, Melbourne, Oceanic Art Pty Ltd.

BüHLER Alfred, 1960. Kunststile am Sepik, Basel, Museum für Völkerkunde.

Craig Barry, 1975. The Art Style of Yellow River, West Sepik District, New Guinea, Baessler-Archiv XXIII, pp. 417-445.

—, 1980a. Introduction to the Legends of the Abau and Amto, West Sepik Province, Oral History 8 (4), pp. 1-58 (revised version 2010 at http://uscngp.com/papers/).

—, 1980b. Legends of the Abau, Idam Valley, West Sepik Province, Oral History 8 (5), pp. 1-92 (revised version 2009 at http://uscngp.com/papers/).

-, 1988. Art and Decoration of Central New Guinea, Aylesbury, Bucks, Shire Publications.

Craig Barry (ed.), 2010a. Living Spirits with Fixed Abodes: The Masterpieces Exhibition of the Papua New Guinea National Museum and Art Gallery, Adelaide, Crawford House Publishing Australia.

Craig Barry, 2010b. Digitisation of Pacific Collections and the Upper Sepik-Central New Guinea Project (http://uscngp.com/papers/).

-, 2012. Carved and Painted Works of the Torricellis, West Sepik Province, Papua New Guinea, Pacific Arts NS 12 (1), pp. 5-20.

—, 2016. Slit Gongs of the Sepik and Madang Provinces (http://uscngp.com/papers/).

Craig Barry, Gilbert Lewis and William E. Mrtchell, 2008. War Shields of the Torricelli Mountains, West Sepik Province, Papua New Guinea, Oceania 78 (3), pp. 241-259.

Craig Barry, Ron Vanderwal and Christine WinTER, 2015. War Trophies or Curios? The War Mu- seum Collection in Museum Victoria 1915-1920, Melbourne, Museum Victoria Publishing.

Craig Barry and Christine Winter, 2016. Richard Thurnwald and Thomas James Rodoni in the upper Sepik region of New Guinea 1914 (http:// uscngp.com/papers/).

Foley William, 2005. Linguistic prehistory in the Sepik-Ramu basin, in A. Pawley, R. Attenborough, J. Golson and R. Hide (eds), Papuan Pasts. Cultural, linguistic and biological histories of Papuan-speaking peoples, Canberra, Pacific Linguistics, ANU, pp. 109-144.

Gell Alfred, 1971. Penis Sheathing and Ritual Status in a West Sepik Village, Man Ns 6 (2), pp. 165-181.

Guddemi Phillip, 1992. We Came from This: Knowledge, Memory, Painting and "Play" in the Initiation Rituals of the Sawiyanō of Papua New Guinea, $\mathrm{PhD}$ dissertation, University of Michigan.

_, 1993. Mumukokolua': Sago spathe paintings among the Sawiyanö of Papua New Guinea, Res 23, pp. 67-82.

—, 2012. Gender, Encompassment, and Ritual: Sago Panel Paintings of the Sawaiyanoo of East Sepik Province, Papua New Guinea, Pacific Arts Ns 12 (1), pp. 20-34.

Haberland Eike, 1963. Schilde vom oberen Sepik aus den Völkerkunde-Museen Frankfurt am Main und Stuttgart, Tribus 12, pp. 105-121.

—, 1965a. Schilde aus der Sepik-Region, Tribus 14, pp. 167-183.

—, 1965b. Ethnographica vom Oberen Sepik aus dem Museum voor Land- en Volkenkunde in Rotterdam, Baessler-Archiv XIII, pp. 41-57.

Harrison Simon, 1990. Stealing People's Names. History and Politics in a Sepik River Cosmology, Cambridge, Cambridge University Press.

Hauser-Schäublin Brigitta, 1989. Kulthäuser in Nordneuguinea, Berlin, Akademie-Verlag.

Hermann Steffen, Gundolf KRÜGer and Kerstin RogGenbuck (eds), 1996. Sagohammer und Konservendose - Einblicke in die Kultur der Gargar in Neuguinea, Göttingen, Institut und Sammlung für Völkerkunde der Universität Göttingen.

Hoogerbrugge Jac, 1995. Notes on the Art of Barkcloth Painting in the Jayapura area, Irian Jaya, Indonesia, in D. Smidt, P. Keurs and A. Trouwborst (eds), Pacific Material Culture, Leiden, Rijksmuseum voor Volkenkunde, pp. 167-179.

Huber Peter B., 1990. Masquerade as Artifact in Wamu, in N. Lutkehaus, C. Kaufmann, W. E. Mitchell, D. Newton, L. Osmundsen and M. Schuster (eds), Sepik Heritage: Tradition 
and Change in Papua New Guinea, Durham, N.C., Carolina Academic Press, pp. 151-159.

Juillerat Bernard (ed.), 1992. Shooting the Sun. Ritual and Meaning in West Sepik, Washington, Smithsonian Institution Press.

Kaeppler Adrienne, Christian Kaufmann and Douglas Newton, 1993. Art océanien, Paris, Citadelles \& Mazenod.

Kaufmann Christian, 1979. Art and Artists in the Context of Kwoma Society, in S.M. Mead (ed.), Exploring the Visual Art of Oceania, Honolulu, University Press of Hawai'i, pp. 310-334.

-, 1985. Postscript: The Relationship between Sepik Art and Ethnology, in S. Greub (ed.), Authority and Ornament. Art of the Sepik River: Papua New Guinea, Basel, Tribal Art Centrel Edition Greub, pp. 33-47.

-, 2003. Korewori. Magic Art from the Rain Forest, Adelaide, Crawford House Publishing; Honolulu, University of Hawai'i Press.

Kelm Heinz, 1966. Kunst vom Sepik II, Berlin, Museum für Völkerkunde.

—, 1968. Kunst vom Sepik III, Berlin, Museum für Völkerkunde.

Kelm Antje and Heinz Kelm, 1980. Sago und Schwein: Ethnologie von Kwieftim und Abrau in Nordost-Neuguinea, Wiesbaden, Franz Steiner.

LAYCOCK Donald, 1973. Sepik Languages Checklist and Preliminary Classification, Pacific Linguistics Series B, No. 25, Canberra, ANU.

—, 1975. Languages of the Sepik Region [Map], Pacific Linguistics Series D, No. 26.

Mitchell William, 1975. Culturally Contrasting Therapeutic Systems of the West Sepik: The Lujere, in T. R. Williams (ed.), Psychological Anthropology, The Hague, Mouton, pp. 409-439.

Newton Douglas, 1971. Crocodile and Cassowary. Religious Art of the Upper Sepik River, New Guinea, New York, Museum of Primitive Art.

—, 1975. Kubru Shields: Style and History, in F. Hartt (ed.), Art Studies for an Editor: 25 essays in memory of Milton $S$. Fox, New York, Abrams, pp. 191-223.

—, 2015. Ahnenbegegnungen. Grundlage Lokaler Identitäten am Oberen Mittelsepik, in P. Peltier, M. Schindlbeck and C. Kaufmann (eds), Tanz der Ahnen. Kunst vom Sepik in Papua-Neuguinea, Munich, Hirmer Publishing House, pp. 96-105.
NiLEs Don, 1983. Why are there no garamuts in Papua? Bikmaus IV (3), pp. 90-104.

Peltier Philippe and Floriane Morin (eds), 2006. Shadows of New Guinea, Geneva, Musée Barbier-Mueller.

Peltier Philippe, Markus Schindlbeck and Christian Kaufmann (eds), 2015. Sepik, arts de Paponasie Nouvelle-Guinée, Paris, Skira, musée du quai Branly.

Peter Hans, 1990. Cultural Changes in Gargar Society, in N. Lutkehaus, C. Kaufmann, W.E. Mitchell, D. Newton, L. Osmundsen and M. Schuster (eds), Sepik Heritage: Tradition and Change in Papua New Guinea, Durham, N.C., Carolina Academic Press, pp. 245-250.

Preuss Konrad Theodor, 1899. Künstlerische Darstellungen aus dem Deutsch-Holländischen Grenzgebiet in Neu-Guinea, Internationales Archiv für Ethnographie XII, pp. 161-185.

Sснміdт E.W., 1929. Die Schildtypen vom Kaiserin-Augusta-Fluss und eine Kritik der Deutung ihrer Gesichtsornamente, Baessler-Archiv 13, pp. 136-177.

Schultze Jena Leonhard, 1914. Forschungen im Innern der Insel Neuguinea: Bericht des Führers über die wissenschaftlichen Ergebnisse der deutschen Grenzexpedition in das westliche Kaiser-Wilhelmsland 1910, Mitteilungen aus den deutschen Schutzgebieten Supplement 11.

Schuster Meinhard, 1969. Die Maler vom May River, Palette 33, pp. 1-19.

Swadling Pamela, Brigitta Hauser-Schäublin, Paul Gorecki and Frank Tiesler, 1988. The Sepik-Ramu. An Introduction, Boroko, PNG, National Museum and Art Gallery.

TiesLer Frank, 1970. Tragbandschilde aus dem Hatzfeldhafen-Gebiet, dem Hinterland der Berlinhafen-Küste und dem Lumi-Gebiet, Nord-Neuguinea, Jahrbuch des Museums für Völkerkunde zu Leipzig 27, pp. 185-217, Tafel xXXIII-LII.

—, 1984. Die Kürasse Neuguineas, Abhandlungen und Berichte des Staatlichen Museums für Völkerkunde, Dresden 41, pp. 46-85, Tafel I-Xxvi.

Van Der Sande Gijbertus Adrian Johan, 1907. Résultats de l'expédition scientifique néerlandaise à la Nouvelle-Guinée en 1903 ..., Nova Guinea III, Ethnology and Anthropology, Leiden, E.J. Brill. 